\title{
CITRA DIRI MASKULIN PARA PELAKU KEJAHATAN SEKSUAL TERHADAP ANAK Studi Kasus di Kabupaten Banyumas Jawa Tengah
}

\author{
Tri Wuryaningsih, Arizal Mutahir, dan Ratna Dewi \\ Universitas Jenderal Soedirman \\ arizal_mutahir@yahoo.com
}

\section{ABSTRAK}

Persoalan kekerasan terhadap anak di Indonesia menjadi persoalan yang sangat serius. Pemerintah menyatakan bahwa 'Indonesia Darurat Kekerasan terhadap Anak.' Kasuskekerasanterhadapanakterus mengalami peningkatan. Kasus kekerasan seksual merupakan kasus terbanyak. Kasus kekerasan seksual tidak lepas dari gagasan maskulinitas yang sangat cenderung patriarkhis. Penelitian ini bertujuan untuk mengkaji dan menjelaskan tentang gagasan maskulin para pelaku kejahatan seksual terhadap anak yang berkenaan dengan makna dan struktur sosial yang melingkupi mereka. Untuk meraih tujuan tersebut, penelitian ini menggunakan pendekatan kualitatif. Temuan penelitian ini adalah: tindakan seksual para pelaku kejahatan seksual tidak dapat dilepaskan dari pemaknaan mereka tentang gender dan seksualitasnya, laki-laki dianggap sebagai sang penakluk, pemangsa, dan perempuan sebagai pihak yang ditundukkan (objek seksual). Bagi kaum paedofil (pelaku sodomi), perempuan adalah sosok yang selalu membuatnya sakit hati. Anak-anak dijadikan pelampiasan hasrat seksualnya; para pelaku kejahatan seksual menganggap persetubuhan dengan anak dilakukan atas dasar suka sama suka, tidak ada ancaman dan paksaan, bukan merupakan kekerasan atau tindak kejahatan; struktur sosial yang melingkupi para pelaku adalah: tingkat sosial ekonomi rendah, 
lingkungan pergaulan buruk, ketiadaan figur ayah, ketiadaan istri dalam jangka waktu lama, cenderung menutup diri dari lingkungannya, konsumsi obatobat terlarang, minuman keras, materi pornografi serta seks bebas.

Kata kunci: Kejahatan Seksual, Anak, Maskulin, Struktur Sosial

\section{ABSTRACT}

"Violence against Children is National Emergency" is the statement delivered by the government to show how the issue of violence against children in Indonesia has become a very serious problem. Currently the case of violence against children is increasing and cases of sexual violence cases occupy the highest among the other kinds of violence. This study aims to analyze and explain the masculine self-image of perpetrators of sexual crimes against children that focuses on the meaning and social structures that surround sexual offenders. The findings in this study are: 1) The sexual act of sexual offenders cannot be separated from their understanding about gender and sexuality, in which the male sex is considered as the conqueror, predators, and women as the subjugated (sexual object). For the pedophile, the woman is a person who always hurt him. Only the children can freely vent to his sexual desires; 2) According to sex offenders, that sexual intercourse with a child is consensual, there is no threat and coercion and it is not a violence or crime; 3) social structure that surrounds the sex offenders are: low level of socio-economic, bad social environment, the absence of a father figure, the absence of the wife in the long term, tend to close themselves from the environment, the consumption of illegal drugs, alcohol and pornographic material as well as free sex.

Keywords: Sexual Crimes, Child, Masculine, Social Structure 


\section{A. Pendahuluan}

Indonesia Darurat Kekerasan terhadap Anak' adalah pernyataan yang disampaikan oleh pemerintah untuk menunjukkan betapa persoalan kekerasan terhadap anak di Indonesia menjadi persoalan yang sangat serius. Komisi Perlindungan Anak Indonesia (KPAI) melaporkan bahwa setiap tahun telah terjadi sekitar 3.700 kasus. Dengan kata lain, ada sekitar 13 hingga 15 kasus kekerasan terhadap anak setiap hari (Alam, 2014). Laporan Komisi Nasional Perlindungan Anak (Komnas PA) menyebut bahwa dalam kurun waktu empat tahun, yakni pada 2010 hingga 2014, ada 21.689.797 kasus yang dilaporkan ke Komnas PA. Kasus tersebut terjadi di 34 provinsi dan 179 kabupaten/kota. Sebanyak 42 persen hingga 58 persen dari pelanggaran hak anak tersebut merupakan kejahatan seksual. Selebihnya adalah kasus kekerasan fisik, penelantaran, penculikan, eksploitasi ekonomi, perdagangan anak untuk eksploitasi seksual komersial serta kasus-kasus perebutan anak (Syafputri, 2014). Data Komnas Perlindungan Anak dalam Kompas Per Juli 2015 (28 Oktober 2015) tentang kekerasan seksual terhadap anak sebagai berikut: 'Kejahatan terhadap Anak: Kekerasan Kian Mengkhawatirkan'

Tabel 1.1. Kasus Kekerasan Seksual terhadap Anak

\begin{tabular}{llccc}
\hline No. & \multicolumn{1}{c}{ Kasus } & Tahun \\
& & 2013 & 2014 & 2015 \\
\hline 1. & $\begin{array}{l}\text { Anak korban tayangan dan } \\
\text { pergaulan seks bebas }\end{array}$ & 120 & 64 & 54 \\
2. & $\begin{array}{l}\text { Anak korban kejahatan seksual } \\
\text { online }\end{array}$ & 23 & 53 & 66 \\
3. Anak pelaku kejahatan seksual \\
online
\end{tabular}




\begin{tabular}{|c|c|c|c|c|}
\hline 4. & $\begin{array}{l}\text { Anak korban pornografi dari } \\
\text { media sosial }\end{array}$ & 147 & 163 & 49 \\
\hline 5. & $\begin{array}{l}\text { Anak pelaku kepemilikian } \\
\text { media pornografi (HP/Video, } \\
\text { dan lain-lain) }\end{array}$ & 61 & 64 & 36 \\
\hline 6. & $\begin{array}{l}\text { Anak sebagai korban kekerasan } \\
\text { seksual (pemerkosaan, } \\
\text { pencabulan, sodomi/pedofilia, } \\
\text { dan lain-lain) }\end{array}$ & 343 & 565 & 67 \\
\hline 7 & $\begin{array}{l}\text { Anak sebagai pelaku kekerasan } \\
\text { seksual (pemerkosaan, } \\
\text { pencabulan, sodomi/pedofilia, } \\
\text { dan lain-lain) }\end{array}$ & 247 & 561 & 43 \\
\hline & $\begin{array}{l}\text { Anak sebagai korban prostitusi } \\
\text { online }\end{array}$ & 60 & 83 & 31 \\
\hline & $\begin{array}{l}\text { Anak sebagai korban eksploitasi } \\
\text { seks komersial anak }\end{array}$ & 51 & 46 & 24 \\
\hline
\end{tabular}

Sumber: Komnas PA

Melihat paparan data di atas, terlihat bahwa permasalahan kekerasan terhadap anak terjadi hampir di semua wilayah. Termasuk juga terjadi di wilayah Jawa Tengah. Badan Pemberdayaan Perempuan, Perlindungan Anak dan Keluarga Berencana (BP3AKB) Provinsi Jawa Tengah melaporkan bahwa pada tahun 2013 terdapat 1035 kasus kekerasan terhadap anak dan 636 (61,45\%) kasus diantaranya berupa kasus kekerasan seksual. Pada Triwulan I tahun 2014, terdapat 249 kasus kekerasan terhadap anak dan 126 (50,60\%) kasus diantaranya merupakan kasus kekerasan seksual. Berbagai kasus tersebut terjadi di kabupaten yang berada dalam lingkup Jawa Tengah, termasuk juga Kabupaten Banyumas.

Di Kabupaten Banyumas, sebagaimana laporan pengaduan yang diterima oleh Pusat Pelayanan Terpadu Perlindungan Korban Kekerasan Berbasis Gender dan Anak (PPT PKBGA), kekerasan terhadap anak juga makin meningkat. Kasus kekerasan seksual juga mendominasi 
diantara jenis kekerasan lainnya. Data secara rinci disajikan pada tabel berikut.

Tabel 1.2. Kasus Kekerasan terhadap Anak di Kabupaten Banyumas

\begin{tabular}{cccc}
\hline Tahun & Kasus KBGA & Kasus KTA & KTA Seksual \\
\hline 2013 & 130 & $52(40 \%)$ & $44(84,61 \%)$ \\
2014 & 110 & $44(40 \%)$ & $38(86,36 \%)$ \\
2015 Per & 81 & $29(35,80 \%)$ & $20(68,97 \%)$ \\
September & & & \\
\hline Jumlah & 320 & 125 & 102 \\
\hline
\end{tabular}

Sumber: PPT PKBGA Kabupaten Banyumas (diolah)

Keterangan:

* KBGA: Kekerasan Berbasis Gender dan Anak

** KTA: Kekerasan terhadap Anak

Berdasarkan data yang telah dipaparkan di atas, terlihat bahwa kekerasan seksual merupakan kasus yang mendominasi diantara bentuk-bentuk kekerasan terhadap anak. Hal ini menggambarkan betapa kekerasan seksual terhadap anak telah menjadi permasalahan yang amat serius. Jika tidak ada tindakan luar biasa untuk mencegahnya, masa depan generasi penerus bangsa ini kian terancam. Apalagi jika melihat para pelakunya. Pelaku kejahatan seksual terhadap anak melibatkan guru, ustadz, PNS, TNI/Polri, buruh, petani, mahasiswa, bahkan pelajar. Kejahatan seksual tidak hanya dilakukan oleh orang dewasa, tetapi juga anak-anak, baik yang masih memiliki hubungan keluarga (orang tua, saudara kandung, saudara tiri), tetangga, teman ataupun pacar (Tomagola, 2000; Poerwandari, 2006; SIGA Kabupaten Banyumas, 2013).

Sanksi hukuman pidana yang cukup tinggi bagi para pelaku kejahatan seksual, sebagaimana diatur dalam UU No. 23 tahun 2002 dan diubah dalam UU No. 35 tahun 
2014 tentang Perlindungan Anak, seolah tak mampu membendung laju kasus kekerasan seksual terhadap anak di Indonesia. Berbagai upaya telah dilakukan pemerintah untuk merespons permasalahan tersebut. Pemerintah telah membentuk Satuan Tugas Perlindungan Anak dan Pusat Pelayanan Terpadu Pemberdayaan Perempuan dan Anak (P2TP2A) dari tingkat pusat hingga tingkat kabupaten/ kota. Namun demikian, kehadiran lembaga-lembaga tersebut belum mampu mengendalikan laju kejahatan seksual terhadap anak.

Selama ini, lembaga yang bergerak di bidang perlindungan anak umumnya hanya fokus pada anak yang menjadi korban kekerasan seksual, dengan menyediakan berbagai layanan seperti layanan pengaduan, penegakan dan bantuan hukum, rehabilitasi medis, rehabilitasi sosial dan reintegrasi sosial. Di lain pihak, perhatian ataupun kajian terhadap pelaku kejahatan seksual tidak banyak dilakukan. Penelitian Woro, dkk. (2015) misalnya, lebih memfokuskan peran guru dalam pencegahan kekerasan terhadap anak. Masih bertema kekerasan terhadap anak, hal sama dilakukan Aprilia (2015). Dia melakukan kajian dengan metode analisis isi terhadap pemberitaan kasus kekerasan terhadap anak dalam keluarga pada Harian Kompas. Selanjutnya, Wiji (2015) juga mengkaji perilaku kekerasan terhadap perempuan dengan menganalisis data sekunder. Berbagai penelitian terdahulu tersebut, belum menyinggung sama sekali tentang bagaimana memahami kejahatan seksual terhadap anak dari perspektif pelaku.

Secara sosiologis perilaku seseorang termasuk di dalamnya para pelaku kejahatan seksual merupakan hasil dari proses interaksi sosial. Bagaimana seseorang memaknai kemudian bertindak terhadap sesuatu tidak terlepas dari struktur sosial yang melingkupinya. Berdasarkan hal tersebut, kajian tentang makna dan struktur sosial yang melingkupi para pelaku kejahatan seksual tersebut 
sangat relevan untuk dilakukan. Bagaimanapun proses rekayasa sosial untuk meminimalisir kasus kejahatan sosial membutuhkan kajian dari berbagai aspek. Melalui kajian ini akan diperoleh berbagai informasi dan data pendukung yang dapat digunakan untuk merumuskan model pencegahan untuk memutus mata rantai tindak kejahatan seksual terhadap anak.

Untuk mencapai tujuan penelitian yang telah disebut di atas, penelitian ini menggunakan pendekatan kualitatif (Denzin dan Lincoln, 2009) tentang makna dan struktur sosial yang melingkupi pelaku kejahatan seksual terhadap anak. Penelitian ini dilakukan di Kabupaten Banyumas. Informan dipilih dengan menggunakan teknik purposive, yang terdiri dari para pelaku kejahatan seksual, masyarakat sekitar tempat tinggal pelaku, penyidik Polres Banyumas, dan relawan pendamping dari PPT PKBGA Kabupaten Banyumas. Pengumpulan data dilakukan sejak April hingga September 2016 dengan cara indeptinterview (Moleong, 1990), observasi dan dokumentasi. Data dianalisis menggunakan analisis deskriptif kualitatif dengan model analisis interaktif yang dikembangkan oleh Miles dan Huberman (1988).

\section{B. Pembahasan}

\section{Kejahatan Seksual terhadap Anak di Mata Pelaku}

Pelaku kejahatan seksual tidak mengenal latar belakang status sosial. Pelaku kejahatan seksual terhadap anak melibatkan guru, ustadz, PNS, TNI/Polri, buruh, petani, mahasiswa, bahkan pelajar. Kejahatan seksual juga tidak hanya dilakukan oleh orang dewasa, tetapi juga anak-anak, baik yang masih memiliki hubungan keluarga (orang tua, saudara kandung, saudara tiri), tetangga, teman ataupun pacar (Tomagola, 2000; Poerwandari, 2006; SIGA Kabupaten Banyumas, 2013). Oleh karena itu, dalam rangka 
mendapatkan informasi yang beragam dan mendalam, penelitian ini berupaya mengeksplorasi informasi dari pelaku tindak kejahatan seksual dipilih berdasarkan jenis kejahatan (sodomi, incest, persetubuhan) yang dilakukan dan usia pelaku (dewasa dan anak-anak).

Membahas persoalan kejahatan seksual tidak dapat dilepaskan dari konstruksi berpikir para pelaku kejahatan dalam memandang dan memaknai perempuan. Konstruksi berpikir atas perempuan tersebut dibalut oleh ideologi patriarki yang masih sangat mendominasi di masyarakat Indonesia. Dalam ideologi patriarki, seseorang memiliki identitas gender laki-laki, maka masyarakat menuntut karakter tertentu yang berkonotasi maskulin dan jantan, seperti agresivitas, keberanian, kepemimpinan dan kekuatan fisik. Artinya menjadi laki-laki, seseorang dituntut untuk membuktikan kekuatan fisik. Sedangkan feminitas dilekatkan pada perempuan yang memiliki karakter lemah lembut, halus dan enggan menonjolkan diri. Dalam hubungan individu, laki-laki diakui maskulinitasnya jika terlayani oleh perempuan. Sementara perempuan terpuaskan feminitasnya jika dapat melayani laki-laki (Saptari dan Holzner: 1997).

Penaklukan terhadap perempuan, sebagai salah satu cara untuk menunjukkan maskulinitasnya atau ke-lakilaki-an-nya adalah cara yang digunakan oleh salah satu pelaku yang bernama DR (17 th). Dalam proses wawancara, DR nampak begitu bangga menceritakan bahwa dia sudah menaklukan 19 orang gadis dan dijadikan sebagai pacar. DR hanya lulusan sekolah dasar (SD), tetapi merasa sangat bangga dengan banyaknya gadis yang dapat dipacarinya. Apalagi dia mendapatkan pacar yang pendidikannya jauh lebih tinggi. Dengan cara seperti itu, DR merasa sebagai seorang laki-laki sesungguhnya. Dalam ungkapan Bahasa Jawa, sering disebut dengan istilah lananging jagad. 
DR remaja asal Mrebet Purbalingga dilaporkan ke Polres Banyumas pada tanggal 27 Maret 2016 atas tuduhan telah melakukan persetubuhan terhadap pacarnya yang bernama Idr (16 tahun) di sebuah hotel di kawasan Baturraden. Menurut DR, apa yang dilakukan terhadap Idr bukanlah sebuah bentuk kejahatan seksual. DR mengungkapkan sebagai berikut:

... saya berpacaran dengan Idr kurang lebih satu tahun. Saya melakukan itu, ya atas dasar suka sama suka. Padha geleme lah (sama-sama maulah). Saya tidak melakukan pemaksaan atau mengancam, walaupun sebelumnya saya berkali-kali merayunya untuk melakukan itu. Awalnya Idr tidak mau karena takut hamil. Lalu saya menjawab nek hamil gampang, mengko tak nikah (kalau hamil gampang, nanti saya nikahi) ... .

Menurut DR tindakan seksual yang dilakukan terhadap Idr bukan sebuah kejahatan seksual. Menurut dia, mereka saat itu berpacaran dan tindakan seksual yang dilakukan atas dasar suka sama suka. Namun demikian, DR mengakui bahwa sebelumnya sering melakukan bujuk rayu terhadap Idr dan berjanji menikahinya jika hamil. DR mengungkapkan bahwa sebelum dengan Idr, dia juga pernah melakukan persetubuhan dengan pacarnya yang bernama Ica. Di usianya yang belum genap 17 tahun, dia sudah terbiasa mengonsumsi materi pornografi dengan menonton film-film porno dari handphone. Laporan orang tua Idr ke Polres Banyumas, tidak hanya karena tindakan seksualnya tetapi juga tindakan menyebarluaskan foto bugil Idr ke media sosial dengan cara menjadikan foto tersebut sebagai display picture (DP) di black berry massanger (BBM) miliknya. DR tidak mengetahui bahwa tindakannya merupakan tindakan pidana yang akan membawanya berurusan dengan penegak hukum. Tindakannya itu diakui karena terdorong oleh emosi. DR marah terhadap Idr dan 
ingin membuat Idr malu. Pleck (2004) menyebut bahwa penguasaan laki-laki terhadap perempuan dilakukan dengan banyak cara. Hal itu dilakukan dalam kerangka untuk memperoleh keuntungan konkret dan privilese sekaligus untuk menunjukkan kekuasaan. Berbagai cara dilakukan lantaran laki-laki merasa cemas dan kemudian menjadi rapuh ketika perempuan melepaskan diri dari kekuasaannya. Apa yang dilakukan DR ketika memasang DP di BBM miliknya merupakan wujud dari perasaan cemas itu meski berdalih ingin membuat Idr malu. Keinginan membuat malu muncul dari hubungan yang bersifat intim (Kabesh, 2013). Sifat maskulin sangat dekat dengan upaya membuat malu. Itu merupakan sebentuk tindakan penundukkan untuk menunjukkan kekuasaan. Tindakan untuk merawat kekuatan dan ego diri yang bersifat ilusif.

Seperti halnya DR, kejahatan seksual juga dilakukan olehremaja bernama HA (16 tahun). HA dilaporkankePolres Banyumas bersama dengan 2 (dua) orang temannya pada 28 Maret 2016 atas tuduhan telah melakukan persetubuhan terhadap seorang gadis berusia 14 tahun, bernama Mawar (bukan nama sebenarnya). Berikut penuturan HA tentang kronologi tindakan seksualnya terhadap Mawar.

... awalnya saya mengenal Mawar lewat sms. Ada teman yang memberi nomer HP-nya. Setelah sms-an, Mawar menyampaikan ingin ikut jalan-jalan. Kemudian kita janjian untuk nonton konser di Purbalingga bersama dua orang teman saya. Mawar kemudian nyamper saya dengan motornya dan kita berboncengan. Kita berangkat berempat (saya, Mawar, Im dan Zk) untuk nonton konser. Sebelum nonton, Mawar menyuruh teman saya membeli pil melopam dengan memberikan uang lima puluh ribu ... . Mawar juga ikut meminumnya. Kita berempat semuanya nge-pil. Ya bikin fly ..., tapi tetap sadar. Mawar juga masih sadar dan ngomongnya juga nyambung. Setelah nonton 
konser, Mawar tidak mau diantar pulang dan masih ingin jalan-jalan padahal sudah larut malam. Dari situ, Imam menyampaikan idenya..., garapi Mawar yuh... (dengan maksud untuk menyetubuhi Mawar -pen.).

Kejahatan seksual terhadap perempuan juga dipengaruhi oleh penilaian pelaku terhadap sikap dan perilaku perempuan. Dalam hal ini, HA menyampaikan bahwa ide untuk garapi Mawar karena dia dan temanteman dia menilai Mawar adalah bocah geleman (perempuan gampangan). HA menuturkan bahwa sebelumnya dia sudah sering mendengar cerita kalau Mawar sering tongkrongan sama anak laki-laki, ikut minum-minum dan nge-pil (mengonsumsi pil koplo). Menurut HA, seharusnya anak perempuan harus bisa menjaga diri, tidak suka keluar malam dengan laki-laki yang baru dikenalnya, tidak ikut-ikut nongkrong seperti anak laki-laki, apalagi sampai ikut minum-minum. Hearn dan Collinson (1994) menyebut bahwa kerap kali laki-laki dan maskulinitasnya diposisikan sebagai pusat dalam masyarakat baik secara eksplisit maupun implisit. Implikasinya adalah dunia sosial dikerangkakan dalam cara berpikir dunia laki-laki. Dunia disesaki arus utama laki-laki (malestream). Perempuan hidup dalam kultur laki-laki. Akibatnya, perempuan hanya sebagai objek cara berpikir dan bertindak laki-laki. Alasan HA ketika melakukan kejahatan seksual terhadapa Mawar merupakan wujud dari kultur laki-laki. Berita Resmi Statistik Badan Pusat Statistik (2017) menyebut bahwa 1 dari 3 perempuan berumur 15-64 tahun pernah mengalami kekerasan seksual semasa hidupnya. Fakta itu, mengikuti Marine (2007), menunjukkan bahwa masyarakat terjangkiti wabah rape culture.

Konstruksi gender memang mengatur apayang pantas bagi laki-laki dan apa yang pantas bagi perempuan sesuai dengan kultur masyarakatnya. MacKinnon (Saraswati, 
2000) menyebut bahwa konstruksi gender patriarki tidak hanya mengakibatkan perempuan menjadi obyek yang pasif, inferior dan dirugikan. Namun, juga menjadikan perempuan sendiri telah belajar untuk menjadi lemah dan tidak berdaya. Ketidakberdayaan perempuan tersebut, baik yang dipelajari secara sadar ataupun secara sukarela ataupun tidak telah membuat perempuan menjadi korban kekerasan.

Munti (2005) menyebut bahwa seksualitas perempuan yang dilekatkan dengan tubuh alamiah mereka dihadaphadapkan dengan laki-laki, diberlakukanlah berbagai oposisi biner seperrti feminin/maskulin, inferior/superior, objek/subjek, pasif/aktif dan seterusnya di mana kualitaskualitas sisi kanan dipandang positif dan superior untuk laki-laki, sedang sisi kiri dipandang negatif dan inferiori bagi perempuan. Seks laki-laki dirumuskan sebagai sesuatu yang secara alamiah tidak kenyang-kenyangnya (superior), dan 'normal' yang mendorong mereka untuk berkuasa. Sementara seks perempuan dimitoskan sebagai seks yang pasif, sehingga seks perempuan tak lebih dari objek hasrat seks laki-laki. Laki-laki sebagai sang penakluk, pemangsa, adalah hal yang normal dan perempuan secara alamiah merupakan pihak yang ditundukkan (objek seksual). Konstruksi sosial seksualitas sebagaimana diuraikan tersebut seringkali termanifestasikan dalam bentuk kekerasan seksual terhadap perempuan ataupun anak-anak.

Kejahatan seksual tidak hanya dilakukan oleh orang asing, pacar, maupun teman akan tetapi juga dilakukan oleh ayah terhadap anak kandungnya sendiri, atau sering disebut dengan incest. Seorang ayah yang seharusnya melindungi anak-anaknya dari kejahatan seksual, pada kenyataannya tidak sedikit yang justru mengorbankan anak kandungnya 
sendiri untuk melampiaskan hasrat seksualnya. Stm adalah seorang laki-laki berumur 42 tahun asal Kecamatan Lumbir, yang dilaporkan ke Polres Banyumas pada 17 Mei 2016 atas tuduhan telah menyetubuhi dan menghamili anak kandungnya sendiri yang bernama Tv (15 tahun) yang masih duduk di kelas X di sebuah SMK. Atas perbuatannya itu, anak kandungnya telah melahirkan seorang bayi perempuan hingga kasusnya diketahui oleh masyarakat. Saat wawancara dengan peneliti, Stm mengakui secara sadar bahwa Ia telah menyetubuhi anak gadisnya hingga hamil.

Stm menyampaikan bahwa dirinya khilaf hingga tega menyetubuhi anak kandungnya sendiri. Namun demikian, tindakan seksual Stm terhadap anaknya bukanlah sebuah bentuk kekhilafan, karena dilakukan berulang kali hingga anaknya hamil. Tindakannya justru menunjukkan bahwa Stm telah menjadikan anak kandungnya sebagai pelampiasan hasrat seksualnya. Stm mengungkapkan bahwa istrinya sudah 7 tahun bekerja menjadi TKW di Taiwan. Istrinya hanya pulang 3 tahun sekali, dan berada di Indonesia paling lama 10 hari. Kondisi ini seolah jadi pembenar bagi Stm untuk menyetubuhi anaknya sendiri. Selain itu, ungkapan Stm bahwa Tv sudah tidak perawan, tidak berontak, tidak marah terhadap dirinya seolah Stm ingin meligitimasi tindakannya.

Dalam relasi dengan orang tua, anak berada dalam posisi subordinat. Anak sangat bergantung dan tidak berdaya. Tidak adanya orang lain selain ayahnya yang dijadikan sebagai tempat bergantung oleh $\mathrm{Tv}$, membuat posisinya semakin lemah. Ibunya bertahun-tahun berada di luar negeri dan kakak satu-satunya, bekerja dan menetap di Jakarta. Kondisi ini dimanfaatkan pelaku untuk mendoktrin anaknya agar tidak menceritakan apa yang 
dialaminya kepada orang lain. Ina (46 tahun), penyidik dari Unit PPA Polres Banyumas yang memeriksa saksi korban (Tv) mengungkapkan sebagai berikut:

... awalnya, Tv itu luar biasa susah untuk dimintai keterangan. Sampai bersumpah bahwa yang menghamili adalah pacarnya. Tapi ketika disuruh menunjukkan pacarnya siapa, alamatnya di mana Tv menjawab tidak tahu. Ketika ditanya kenal di mana, dia menjawab di FB tetapi ketika disuruh menunjukkannya, Tv menjawab FB nya sudah dihapus. Lama sekali saya harus ngarih-ngarih, sambil tak elus-elus pundaknya, baru dia nangis sekeraskerasnya dan mengakui bahwa yang menghamili adalah ayahnya sendiri. Anak itu kelihatannya sudah didoktrin Bu. Jan..., awalnya terus saja nutupi... .

Menurut Poerwandari (2006) kerentanan akan kekerasan seksual dihadapi oleh anak-anak baik perempuan atau laki-laki. Umumnya anak masih memiliki ketergantungan yang besar pada orang dewasa, baik itu ketergantungan ekonomi (tidak mampu menghidupi diri sendiri), ketergantungan sosial (tahap perkembangannya belum memungkinkannya mandiri secara sosial), juga ketergantungan emosional (anak butuh orang yang memberi kasih sayang dan melindungi). Orang dewasa dapat saja, dengan kekuasaan dan posisinya yang superior, bersikap sewenang-wenang pada anak, termasuk dengan melakukan kekerasan seksual. Menurut Sirait (2014) anak sebagai sosok yang lemah merupakan kelompok paling rentan dalam situasi apapun dalam keluarga, masyarakat dan negara. Anak sebagai individu yang tidak mampu membela dan melindungi dirinya sendiri.

Kejahatan seksual di Kabupaten Banyumas tidak hanya menimpa anak-anak perempuan, tetapi juga anak laki-laki. BM (38 tahun) adalah salah satu pelaku sodomi terhadap puluhan anak laki-laki (usia 14-15 tahun) yang 
dilaporkan ke Polres Banyumas pada awal Juli 2016. Dalam wawancara dengan peneliti, BM menceritakan bahwa tindak kejahatan seksualnya pertama kali dilakukan di Cirebon, dengan korban sebanyak 7 orang anak. Atas kejahatannya BM diganjar dengan pidana penjara selama 3 tahun 7 bulan di Lapas Cirebon pada tahun 2007.

Dengan alasan mencari pekerjaan, BM meninggalkan Cirebon untuk mengadu nasib di Purwokerto. Baru beberapa bulan di Purwokerto, BM mulai berkenalan dengan anak-anak dan membujuknya untuk latihan bela diri di kost-nya. Pertama kali, ia bertemu dengan Sofyan. Melalui Sofyan, BM mencari anak-anak yang mau latihan bela diri. Anak-anak tergiur untuk mengikuti ajakan BM karena latihannya tidak ditarik biaya. Atas bantuan Sofyan, ada 10 anak yang kemudian mengikuti latihan bela diri di tempat BM. Dengan modus menyalurkan tenaga dalam, BM kembali menyalurkan hasrat seksualnya kepada anakanak tersebut. Lebih lanjut BM mengungkapkan bahwa ada rasa sakit hati terhadap perempuan, sehingga lebih senang menyalurkan hasrat seksualnya terhadap anak laki-laki. Berikut penuturannya:
“... iya saya sempat beberapa kali berpacaran dengan perempuan, namun semuanya putus di tengah jalan. Semua perempuan yang saya pacari selalu matere (mata duwitan) minta ini dan itu dan hanya membuat saya sakit hati. Akhirnya keinginan berpacaran dengan laki-laki muncul lagi, tapi ya baru beberapa bulan putus juga."

Mendasarkan pada cerita BM, anak-anak merupakan sosok yang mudah diperdaya sehingga dengan mudah dijadikan sebagai alat untuk melampiaskan hasrat seksualnya. Dengan modus memberikan ilmu bela diri dan menyalurkan tenaga dalam, anak-anak dibujuk untuk menuruti keinginannya. Rata-rata anak-anak yang menjadi korban adalah anak yang akan dan tengah mengalami 
masa pubertas. Masa pubertas, adalah masa dimana anakanak sedang mencari jati diri. Mereka masih mencari bentuk-bentuk tindakan untuk memperkuat rasa percaya diri. Dorongan untuk mendapatkan rasa percaya diri yang berlebihan di kalangan anak-anak tersebut, dengan cara menguasai tenaga dalam sehingga tidak mempan senjata tajam, telah dimanipulasi oleh pelaku kejahatan. Sehingga mereka tidak menyadari jika yang dilakukan oleh BM adalah sebuah tindak kejahatan seksual.

Pengalaman BM dipenjarakan tidak lantas membuatnya jera dan menghentikan tindak kejahatannya. Ina (46 tahun), penyidik dari Unit PPA Polres Banyumas, menjelaskan bahwa berdasarkan hasil koordinasi dengan Polres Cirebon, BM kembali melakukan kejahatan seksual terhadap anak selepas dirinya keluar dari penjara. BM melarikan diri ke Purwokerto dan masuk dalam daftar pencarian orang (DPO) Polres Cirebon. Dengan kejahatan yang berulang tersebut, BM dituntut dengan pidana penjara 15 tahun oleh Jaksa Penuntut Umum (JPU) di Pengadilan Negeri Banyumas. Dengan pertimbangan bahwa pelaku sudah berulang kali melakukan kejahatan, majelis hakim memberikan hukuman yang lebih tinggi dari tuntutan JPU, yaitu dengan vonis 17 tahun pidana penjara.

Bagi para pelaku, sebagaimana diungkapkan oleh DR, HA dan Stm, melakukan persetubuhan dengan anak yang mereka lakukan didasarkan atas dasar suka sama suka, tidak ada ancaman dan paksaan. Mereka menganggap perilaku mereka bukan merupakan kekerasan atau tindak kejahatan. Sedangkan bagi BM, perempuan adalah sosok yang selalu membuatnya sakit hati. Hanya dengan anak-anak BM dapat melampiaskan hasrat seksualnya dengan leluasa. Kekerasan mempunyai ciri khas pemaksaan, sedangkan pemaksaan dapat mengambil wujud pemaksaan persuasif dan pemaksaan fisik, atau gabungan keduanya. Kekerasan, 
seperti yang diuraikan oleh Lardellier (Haryatmoko, 2007), bisa didefinisikan sebagai prinsip tindakan yang mendasarkan diri pada kekuatan untuk memaksa pihak lain tanpa persetujuan. Dalam kekerasan terkandung unsur dominasi terhadap pihak lain dalam berbagai bentuknya: fisik, verbal, moral, psikologis, atau melalui gambar.

Pernyataan para pelaku kejahatan seksual seperti DR, HA, dan Stm, menunjukkan bahwa mereka tidak memahami bahwa dengan alasan apapun mereka dilarang menyetubuhi anak di bawah umur. Anak, sebagaimana dijelaskan dalam Undang-Undang Perlindungan Anak, adalah "seseorang yang belum berusia 18 (delapan belas) tahun, termasuk anak yang masih dalam kandungan". Larangan menyetubuhi anak dan sanksi bagi yang melanggar larangan tersebut, secara jelas disebutkan dalam Pasal 81, ayat 1, 2 dan 3 Undang-Undang Nomor 35 tahun 2014. Undang-undang tersebut merupakan undangundang perubahan atas Undang-Undang Nomor 23 tahun 2002 tentang Perlindungan Anak. Adanya undang-undang perlindungan anak menunjukkan bahwa anak harus dilindungi. Para pelaku kejahatan seksual tidak memahami tentang hal itu. Artinya, para pelaku kejahatan seksual gagal memahami proses interaksi yang berlangsung dalam masyarakat.

Schutz (Schwandt, 1997) menjelaskan bahwa setiap individu berinteraksi dengan dunia menggunakan 'bekal pengetahuan' yang terdiri atas konstruksi-konstruksi dan kategori-kategori 'umum'. Bekal pengetahuan adalah satusatunya sumber yang memungkinkan setiap individu untuk menginterpretasi pengalaman, memahami maksud dan motivasi individu lain, memperoleh pemahaman intersubjektif dan pada akhirnya mengupayakan tindakan.

Mendasarkan pada pemikiranSchutz, dapatdijelaskan bahwa pemahaman para pelaku terhadap perempuan atau 
anak dan seksualitasnya, akan mempengaruhi cara mereka membangun relasi dan komunikasi dengan perempuan dan anak. Hal tersebut juga mempengaruhi cara bertindak terhadapnya. Sementara itu, menurut Herbert Blumer, manusia bertindak (act) terhadap sesuatu (thing) atas dasar makna (meaning) yang dipunyai sesuatu tersebut baginya. Makna yang dipunyai tersebut muncul dari interaksi sosial di antara dan antarindividu. Makna-makna itu ditetapkan dan dimodifikasi melalui suatu proses interpretatif. Maknamakna digunakan dan direvisi sebagai alat yang menuntun dan membentuk tindakan (Schwandt, 1997). Melalui pemikiran Blumer ini dapat dijelaskan bahwa tindakan seksual pelaku sangat bergantung dari bagaimana mereka memandang dan memberi makna terhadap korbannya (perempuan dan anak) tersebut.

Tindakan-tindakan kejahatan seksual yang dilakukan para pelaku kejahatan seksual di atas juga menunjukkan bahwa para pelaku kejahatan seksual menampilkan maskulintas yang lebih kasar (hard masculinity). Menurut MacKinnon (2003) hard masculinity bersifat opresif dan lebih memamerkan kekuasaan secara fisik. Maskulitas jenis itu berbeda dengan maskulinitas yang lebih lunak (soft masculinity). Maskulinitas lebih lunak cenderung terkesan bersifat feminin ketimbang maskulin. Maskulintas yang lunak adalah versi maskulinitas yang tidak opresif. Maskulinitas ini tidak menyerang, malah lebih membentuk tatanan yang tidak seksis dan anti-opresif ketika berelasi dengan perempuan atau laki-laki.

\section{Struktur Sosial yang Melingkupi para Pelaku Kejahatan Seksual terhadap Anak}

Secara sosiologis, perilaku seseorang merupakan hasil dari proses interaksi sosial. Bagaimana seseorang memaknai kemudian bertindak terhadap sesuatu tidak 
terlepas dari struktur sosial yang melingkupinya. Penelitian ini berupaya mengeksplorasi dan menjelaskan struktur sosial yang melingkupi para pelaku kejahatan seksual. Penelitian ini berusaha menelusuri struktur sosial para pelaku kejahatan seksual dengan menggali informasi tentang latar belakang sosial ekonomi keluarga dan relasi sosial yang dikembangkan oleh para pelaku kejahatan seksual. Berikut ini adalah analisis struktur sosial yang melingkupi para pelaku kejahatan seksual.

DR adalah remaja berusia 17 tahun asal Mrebet Purbalingga.SelepaslulusSD,DRtidakmelanjutkan sekolah dan bekerja sebagai buruh cat di sebuah bengkel motor. DR adalah anak ke 4 dari 5 bersaudara, dimana 2 orang diantaranya merupakan saudara tiri. Ayah DR meninggal sejak dia masih duduk di kelas 6SD. Ibunya bekerja sebagai pengepul idep (bulu mata). DR menceritakan bahwa dia sudah malas melanjutkan sekolah. Dia beralasan temantemannya juga banyak yang tidak melanjutkan sekolah. DR bercerita bahwa dia sudah seringkali berpacaran, ada sekitar 19 remaja yang pernah dipacarinya. Pengalaman yang luar biasa untuk seorang remaja yang belum genap berusia 17 tahun.

DR menceritakan bahwa dIa sering menonton film porno yang diperoleh dari teman-temannya. Melalui teman pergaulannya itu pula, DR mengenal minuman beralkohol seperti anggur kolesom yang dia beli di sekitar Purbalingga. DRjuga menjadi anggota geng motor yang sering melakukan kumpul-kumpul dan touring. Berdasarkan hasil wawancara tergambar bagaimana struktur sosial yang melingkupi kehidupan DR yaitu tingkat pendidikan yang rendah, saat menginjak usia remaja hanya dibesarkan oleh seorang ibu sehinggga kurang pengawasan dari orang tua, bergabung dan bergaul dengan geng motor yang membawa pengaruh buruk seperti mengonsumsi minuman keras, menonton 
film-film porno dan di usianya yang masih remaja sudah mengenal seks bebas.

Seperti halnya DR, latar sosial HA relatif mempunyai kemiripan. HA adalah remaja berusia 16 tahun yang masih berstatus sebagai pelajar kelas IX di sebuah MTs. Dia adalah anak kedua dari 5 bersaudara. Sejak kelas 6 SD, HA ditinggal ayahnya untuk bekerja sebagai TKI di Malaysia. Sejak itu, ayahnya belum pernah pulang ke rumah dan tidak pernah berkomunikasi dengan dirinya. Untuk menopang hidupnya, Ibunya membuat jajanan untuk dititipkan ke warung-warung.

HA menceritakan bahwa dia berteman dengan Im (16 tahun) dan Fsl (16 tahun). Mereka sama-sama satu sekolah. Im dan Fsl dikenal sebagai anak yang mbejut (nakal) di sekolah. Menurut HA, dari mereka juga dia mendapatkan film-film porno. Mereka menonton film tersebut bersamasama. Setelah menonton, mereka terdorong untuk mencobanya. HA belum pernah melakukan hubungan seksual. Dia melakukan baru dengan Mawar. Itupun, menurutnya, karena terdorong teman-temannya yang juga melakukan persetubuhan dengan Mawar.

Mendasarkan pada hasil wawancara, tergambar bagaimana struktur sosial yang melingkupi HA kurang lebih sama dengan DR. Terlihat bahwa HA juga berada dalam lingkungan ekonomi yang kurang mampu. Saat menginjak usia remaja, HA ditinggal ayahnya bekerja ke luar negeri. Dia dibesarkan oleh seorang ibu sehingga kurang pengawasan ketika bergaul dengan teman-teman yang kurang baik. Pergaulan itu membawanya mengenal pornografi, obat-obat terlarang dan seks bebas.

Hyde (1990) menjelaskan ada beberapa faktor yang menyebabkan terjadinya perilaku seks bebas di kalangan 
remaja. Pertama, teman sebaya (peers group). Hal tersebut dikarenakan remaja cenderung untuk membuat standar seksual sesuai dengan standar teman sebaya secara umum. Remaja cenderung untuk menjadi lebih aktif secara seksual apabila memiliki kelompok teman sebaya. Apalagi apabila mereka mempercayai bahwa teman sebayanya aktif secara seksual.

Kedua, pengalaman pacaran/kencan (hubungan afeksi). Individu yang menjalin hubungan afeksi/pacaran sejak umur lebih dini, cenderung lebih permisif terhadap perilaku seks bebas. Begitu juga halnya dengan individu yang telah lebih banyak berpacaran daripada individu yang berusia sebaya dengannya.

Ketiga, ketidakhadiran ayah. Remaja yang tumbuh dan berkembang dalam keluarga tanpa ayah lebih mungkin untuk mencari hubungan seks bebas sebagai alat untuk menemukan afeksi dan persetujuan sosial daripada remaja yang tumbuh dengan adanya ayah.

Keempat, penyebaran informasi melalui media massa. Kecenderungan pelanggaran makin meningkat oleh karena adanya penyebaran informasi dan rangsangan seksual melalui media massa. Adanya teknologi yang semakin berkembang (video kaset, foto kopi, vcd, hp, internet) menjadikan pelanggaran tidak terbendung lagi. Remaja yang sedang dalam periode ingin tahu dan ingin mencoba, akan meniru apa yang dilihat atau didengarnya dari media massa

Struktur sosial yang melingkupi pelaku kejahatan seksual hingga mereka melakukan kejahatan tidak hanya terjadi pada kalangan remaja. Hal itu juga berlaku pada orang dewasa yang melakukan kejahatan seksual. Stm, misalnya. Laki-laki berusia 42 tahun berasal dari Kecamatan Lumbir yang sehari-harinya bekerja sebagai 
petani ini, dilaporkan ke Polres Banyumas pada 17 Mei 2016 atas dugaan telah menyetubuhi dan menghamili anak kandungnya sendiri. Di lingkungannya, Stm dan anaknya dikenal sangat tertutup dan jarang keluar rumah. Stm jarang sekali keluar rumah sekalipun hanya untuk berkumpul dan mengobrol dengan tetangga. Rumahnya selalu tertutup. Anak gadisnya hanya terlihat keluar rumah jika diantar ayahnya.

Ibu Rsm (50 tahun), tetanggga Stm, menuturkan bahwa ada yang tidak wajar jika mengamati hubungan antara Stm dan anak gadisnya itu. Bukan seperti hubungan antara ayah-anak, tetapi seperti orang yang sedang berpacaran. Tv selalu memeluk ayahnya dengan mesra saat diantar berboncengan motor oleh Stm. Menurut ibu Rsm, Tv juga sangat jarang sekali bermain dengan teman sebayanya.

Sejak ditinggal istrinya bekerja di Hongkong, Stm memang hanya tinggal berdua dengan anak gadisnya. Sudah 7 tahun istrinya bekerja di LN. Selama 7 tahun itu, istrinya pernah pulang sebanyak 2 kali. Istrinya berada di rumah paling lama 10 hari, terus berangkat lagi. Anak lakilakinya yang bernama Fj sudah lama bekerja dan tinggal di Jakarta. Sehingga di rumah tidak ada orang, selain Stm dan anak perempuannya.

Berbeda dengan DR dan HA, Stm tidak mengenal materi pornografi, minum-minuman keras ataupun obatobat terlarang. Namun demikian, Stm agak menutup diri dari lingkungannya. Hal itu menjadikannya kurang memiliki wawasan yang luas. Ketiadaan istri dalam waktu yang lama dan situasi rumah yang sepi serta kurangnya pergaulan dengan dunia luar, telah mendorong Stm untuk melampiaskan hasrat seksualnya kepada anak kandungnya sendiri. 
Restuadhi (2016) dalam kajiannya tentang suami buruh migran di Kabupaten Banyumas menjelaskan bahwa kepergian buruh migran perempuan (BMP) ke luar negeri untuk memperbaiki kesejahteraan keluarga ternyata menimbulkan suatu permasalahan baru terkait dengan kebutuhan biologis para suami BMP tersebut. Bagi para suami yang mampu berpikir kreatif, mereka akan menyibukkan diri dengan kegiatan produktif. Namun, terdapat para suami BMP yang tidak dapat menahan kebutuhan biologis mereka sehingga mereka melakukan hubungan seks dengan orang lain atau PSK (Pekerja Seks Komersial) selama istri di luar negeri. Perilaku tersebut tentu saja sangat berisiko terhadap penularan penyakit menular seksual (PMS) atau HIV/ AIDS.

Kabupaten Banyumas sendiri merupakan salah satu kantong buruh migran perempuan di Provinsi Jawa Tengah. Beberapa kasus kekerasan seksual yang dilakukan para suami buruh migran terhadap anak kandungnya yang sempat terungkap dan dilaporkan ke Pusat Pelayananan Terpadu Perlindungan Korban Kekerasan Berbasis Gender dan Anak (PPT PKBGA) Kabupaten Banyumas tidaklah sebeberapa jika dibandingkan dengan kasus yang tidak dilaporkan. Menurut SS (28 tahun) hal itu merupakan fenomena gunung es. Artinya apa yang tampak bukan mencerminkan apa yang sesungguhnya terjadi. Apa yang terjadi sesungguhnyajauh lebih banyak, tetapi ada beberapa penyebab yang membuat kasusnya tidak terlaporkan.

Posisi seseorang dalam struktur sosial yang menjadikan mereka melakukan kejahatan seksual juga terlihat pada BM. Laki-laki berusia 38 tahun asal Cirebon itu adalah anak bungsu dari 8 bersaudara. Saudaranya ada yang bekerja sebagai tukang jahit, buruh bangunan dan buruh serabutan. Tidak ada yang bekerja sebagai pegawai kantoran. BM merasakan hidupnya semakin susah ketika ayahnya meninggal dan ibunya menikah lagi pada saat 
ia masih sekolah di SLTA. Sejak itulah BM, yang saat itu usianya masih 16 tahun memutuskan untuk mengikuti ajakan orang untuk menekuni dunia modeling di Jakarta.

Di Jakarta, BM berkenalan dengan seseorang. Namun, orang tersebut juga yang pertama kali dan berulangkali melakukan sodomi terhadap dirinya. BM menceritakan bahwa pada awalnya dia merasakan sakit ketika disodomi, tetapi lama kelamaan dia mulai menikmati tindakan seksual tersebut. Dia menceritakan bahwa dia tidak bisa menolak tindakan sodomi tersebut karena merasa takut. Apalagi orang tersebut yang memberinya makan dan uang selama menjalani pekerjaannya di dunia modelling. Dia tidak pernah menceritakan kepada siapa pun tentang tindakan seksual yang dialaminya.

Apa yang terjadi selanjutnya adalah justru dia merasa ketagihan akan tindakan seksual menyimpang tersebut. Orientasi seksual menyimpang tersebut kemudian dia rasakan sebagai hal biasa. Dia juga menjalin pacaran dengan sesama model laki-laki. Setelah tamat SMA di Cirebon, BM sempat melanjutkan kuliah hingga semester 6 di Universitas Padjajaran Bandung, FKIP jurusan Bahasa Inggris. Namun, karena ketiadaan biaya, akhirnya memutuskan untuk keluar. Orangtua dan keluarganya yang pas-pasan tidak sanggup membiayai kuliahnya. Sejak itulah dia meraskan hidupnya tidak karuan.

Mencermati pengalaman BM, terlihat bahwa dia berasal dari lingkungan ekonomi yang pas-pasan. Ibunya menikah lagi setelah ayahnya meninggal. Dia mendapatkan kekerasan seksual berupa sodomi di saat pubertas. Dia juga berada di lingkungan sosial dengan kehidupan seksual menyimpang. Semua hal tersebut merupakan struktur sosial yang telah berkontribusi membentuk BM untuk menjadi seorang paedofil.

Erlinda, dari Komisi Perlindungan Anak Indonesia (KPAI) menyebut bahwa para korban pencabulan, 
khususnya sodomi, kerap berpotensi mendorong korban menjadi pelaku. Potensinya lebih dari 70 persen. Sementara itu, Pengamat Sosial Budaya Universitas Indonesia, Devi Rahmawati ikut membenarkan jika trauma kekerasan seksual di masa lalu menjadi pemicu seorang anak tumbuh menjadi seorang paedofil. Namun demikian, potensi menjadi pelaku bukan hanya karena pernah menjadi korban, tetapi media yang menayangkan berbagai adegan seks yang belum layak ditonton yang sekarang sangat mudah dikonsumsi anak-anak di bawah umur, juga dapat menjadikan seseorang menjadi paedofil. Belum lagi ditambah kemudian mendapat akses melalui gadget atau alat elektronik penyedia aplikasi gambar dan video (megapolitan.kompas.com).

Anak-anak korban paedofilia perlu diberikan terapi yang memadai dalam pemulihan pasca-trauma. Pasalnya, mereka berpotensi menjadi pelaku dari kelainan seksual paedofilia (memiliki orientasi seksual pada anak). Menurut Naek L Tobing, secara tidak sadar, anak-anak korban paedofilia, khususnya yang melakukan sodomi, melakukan hubungan seks kali pertama dengan cara disodomi. Oleh karena itu, mereka pun memiliki potensi untuk melakukan tindakan yang sama saat dewasa. Apalagi jika mereka menerima perlakuan itu berulang kali, potensinya bisa jadi lebih tinggi (health.kompas.com).

Banyak faktor yang menjadi penyebab terjadinya tindak kekerasan terhadap anak, antara lain: 1) Anak mengalami cacat tubuh, retardasi mental (keterlambatan dalam perkembangan mental), gangguan tingkah laku, autisme, terlalu lugu, memiliki temperamen lemah, ketidaktahuan anak akan hak-haknya, dan terlalu bergantung kepada orang dewasa. 2) Kemiskinan keluarga, banyak anak. 3) Keluarga pecah (broken home) akibat perceraian, ketiadaan ibu dalam jangka panjang, atau keluarga tanpa ayah. 4) Keluarga yang belum matang 
secara psikologis, ketidakmampuan mendidik anak, harapan orang tua yang tidak realistis, anak yang tidak diinginkan (unwanted child), anak lahir di luar nikah. 5) Penyakit gangguan mental pada salah satu orang tua. 6) Pengulangan sejarah kekerasan: orang tua yang dulu sering ditelantarkan atau mendapat perlakukan kekerasan sering memperlakukan anak-anaknya dengan pola yang sama, serta 7) Kondisi lingkungan sosial yang buruk, keterbelakangan (Sakti, 2014).

\section{Simpulan}

Tindakan seksual para pelaku kejahatan seksual tidak dapat dilepaskan dari pemaknaan mereka tentang gender dan seksualitasnya, dimana seks laki-laki dianggap sebagai sang penakluk, pemangsa, dan perempuan sebagai pihak yang ditundukkan (objek seksual). Namun demikian, bagi kaum paedofil (pelaku sodomi), perempuan adalah sosok yang selalu membuatnya sakit hati. Hanya dengan anak-anak dapat melampiaskan hasrat seksualnya dengan leluasa. Para pelaku kejahatan seksual beranggapan bahwa persetubuhan dengan anak yang dilakukan atas dasar suka sama suka. Mereka menyebut bahwa mereka tidak melakukan ancaman dan paksaan sehingga mereka beranggapan bahwa apa yang mereka lakukan bukan merupakan kekerasan atau tindak kejahatan. Mereka tidak memahami bahwa dengan alasan apapun, dilarang menyetubuhi anak di bawah umur sebagaimana dijelaskan dalam Undang-Undang Perlindungan Anak. Tingkat sosial ekonomi yang rendah, lingkungan pergaulan yang buruk, ketiadaan figur ayah, ketiadaan istri dalam jangka waktu yang lama, cenderung menutup diri dari lingkungannya, konsumsi obat-obat terlarang, minuman keras dan materi pornografi serta seks bebas, semuanya merupakan struktur sosial yang melingkupi para pelaku kejahatan seksual di Kabupaten Banyumas. 


\section{DAFTAR PUSTAKA}

Alam, Syariful, 2014, "KPAI: Setiap Tahun Terjadi 3.700 Kasus Kekerasan Terhadap Anak, ," diakses pada 10 November 2015, dalam http://rri.co.id/ post/berita/104143/nasional/kpai_setiap_tahun_ terjadi_3700kasus_kekerasan_terhadap_anak.html

Aprilia, Mely Ardila, 2015 'Analisis Kasus Kekerasan terhadap Anak dalam Keluarga pada Harian Kompas Tahun 2014,' Laporan Penelitian Fisip Unsoed, Purwokerto.

Badan PusatStatistik, 2017, Berita ResmiStatistik No.29/03/ Th. XX, 30 Maret

Haryatmoko, 2007, Etika Komunikasi, Penerbit Kanisius, Yogyakarta,

Hearn, Jeff and Collinson. David L, 1994, 'Theorizing Unities and Differences Between Men and Between Masculinities,' dalam Brod, Harry and Kaufman, Michael (ed.),. Theorizing Masculinities, Sage, California, USA,

Hyde J.S. 'Sexual Anatomy' dalam Janet S.H ed: Understanding Human Sexuality. USA :McGraw-Hill Publishing Company. p. 55-60, 1990

Kabesh, Amal Treacher, 2013, Postcolonial Masculinities : Emotions, Histories And Ethics, Ashgate, Farnham, England,

Kompas, 2014, "Korban Paedofilia Berpotensi Jadi Pelaku Saat Dewasa?," diakses pada 30 Oktober 2016 http:/ / health.kompas.com/read/2014/04/17/1048594/ Korban.Paedofilia.Berpotensi.Jadi.Pelaku.Saat. Dewasa 
Kompas, 2015 "Mencegah Lingkaran Setan Korban Pencabulan Menjadi Pelaku,", diakses pada 30 Oktober 2016dala http:/ / megapolitan.kompas.com/ $\mathrm{read} / 2015 / 09 / 10 / 10355031 /$ Mencegah.Lingkaran. Setan.Korban.Pencabulan.Menjadi.Pelaku?page=all

Kompas, 2015, Kejahatan terhadap Anak: Kekerasan Kian Mengkhawatirkan diakses pada 28 Oktober 2015 dalam http://print.kompas.com/baca/regional/ metropolitan / 2015/10/28 / Kekerasan-KianMengkhawatirkan,

MacKinnon, Kenneth,. Representing Men. Maleness and Masculinity in the Media, Arnold, New York, USA, 2003 Marine, Susan, 2007, 'Rape,' dalam Flood, Micheal .at. all, International Encyclopedia of Men and Masculinities, Routledge, New York, USA,

Miles, B. Mattew dan A. Michael Huberman,1988, Qualitative Data Analysis: A Sourcebook of New Methods, Seventh Printing, Sage Publications, Beverly HillsLondon-New Delhi,

Moleong, Lexy J., 1990, Metodologi Penelitian Kualitatif. PT Remaja Rosdakarya. Bandung,

Munti, Ratna Batara,2005, Demokrasi Keintiman: Seksualitas di Era Global, LKiS, Yoyakarta,

Pleck, Joseph H, 2004, 'Mens Power with Women, Other Men, and Society,' dalam Murphy, Peter F., Feminism and Masculinities, Oxford University Press, Oxford, UK,

Poerwandari, Kristi, 2006, Penguatan Psikologis untuk Menanggulangi Kekerasan dalam Rumah Tangga dan Kekerasan Seksual, Program Kajian Wanita UI Jakarta, 
Restuadhi, Hendri, 2016, Suami Buruh Migran: Antara Hasrat Seksual dan HIV/AIDS, Jurusan Sosiologi Fisip Universitas Jenderal Soedirman \& PPGAPM LPPM Universitas Jenderal Soedirman, Purwokerto kerja sama dengan Penerbit Tanah Air Beta, Yogyakarta,

Sakti, Hastaning, 2014, 'Dampak Psikologis Korban Kekerasan Berbasis Gender dan Anak.'. Makalah pada Seminar Nasional "Pencegahan dan Penanganan Kekerasan Berbsis Gender dan Anak". 31 Mei 2014. RSUD Margono Soekarjo. Purwokerto

Saptari, Ratna dan Holzner, Brigitte, Perempuan Kerja dan Perubahan Sosial, Kalyana Mitra Jakarta, 1997

Saraswati, Luh Ayu, 2000, Kekerasan Negara, Perempuan dan Refleksi Negara Patriarki, dalam Nur Iman Subono, Negara dan Kekerasan terhadap Perempaun, Yayasan Jurnal Perempuan dan The Asia Foundation, Jakarta

SIGA Kabupaten Banyumas 2013

Sirait, Arist Merdeka, 2014, 'Peran Orang tua Menjaga dan Melindungi Anak dalam Perspektif Perlindungan Anak.' Makalah pada Seminar Nasional "Pencegahan dan Penanganan Kekerasan Berbsis Gender dan Anak". 31 Mei 2014. RSUD Margono Soekarjo. Purwokerto

Syafputri, Ella, 2014, "21 juta kasus kekerasan menimpa anak Indonesia,", diakses pada 10 November 2015 dalam http://www.antaranews.com/ berita/460296/21-juta-kasus-kekerasan-menimpaanak-indonesia,

Tomagola, Tamrin A., 2000, "Restu Sosial Budaya atas

Kekerasan terhadap Perempuan," dalam Nur Iman Subono, Negara dan Kekerasan terhadap Perempaun, 
Yayasan Jurnal Perempuan dan The Asia Foundation, Jakarta

Wiji, Eka, 2015 'Perilaku Kekerasan terhadap Perempuan di Kabupaten Banyumas (sebuah Studi Dokumentasi),' Laporan Penelitian Fisip Unsoed, Purwokerto

Woro, L. Dwi Diyah, dkk., 2015, ‘Menyelamatkan Anak dari Kekerasan: Peran Guru dalam Mencegah Kekerasan pada Anak,' Laporan Penelitian LPPM Unsoed, Purwokerto, 